\title{
Translating Storylines: Challenges in Conveying the Heart of Museum Keris Nusantara Surakarta
}

\author{
Ardianna Nuraeni ${ }^{1}$, Muhammad Taufiq Al Makmun ${ }^{2}$, Nur Saptaningsih ${ }^{3}$, \\ Dyah Ayu Nila Khrisna ${ }^{4}$ \\ ardianna n@staff.uns.ac.id ${ }^{1}, \underline{\text { muhammadtaufiq@staff.uns.ac.id }}{ }^{2}$.nursaptaningsih@ @staff.uns.ac.id ${ }^{3}$, \\ dahayu@staff.uns.ac.id ${ }^{4}$ \\ English Diploma 3 Program, Vocational School, UNS, Indonesia ${ }^{1}$, English Department, UNS, \\ Indonesia ${ }^{2}$, English Diploma 3 Program, Vocational School, UNS, Indonesia ${ }^{3}$, \\ English Department, UNS, Indonesia ${ }^{4}$
}

\begin{abstract}
A great quantity of information about kris in Museum Keris Nusantara is mainly provided in storylines, an informative device telling a worth remembering story that draws museum visitors' attention. Unfortunately, they have not been provided in English, which affect the provision of significant information about kris to foreign visitors. The museum has been involving English Diploma 3 (ED 3 ) students of Universitas Sebelas Maret (UNS) in the project of translating storylines. This paper aims to discuss challenges in translating storylines in Museum Keris Nusantara encountered by 10 intern students of ED 3 UNS. This descriptive qualitative research is completed by: interviewing the students, conducting textual analysis of the translation, and scrutinizing the students' internship reports. The findings show that Javanese-culture-specific terms are not easily conveyed in English. Furthermore, aspects of meaning related to values, cultural and community symbols, and history are often overlooked although the terms can be conveyed acceptably.
\end{abstract}

Keywords: storylines, Museum Keris Nusantara, kris, translation, challenges.

\section{Introduction}

Museum Keris Nusantara (MKN) that is located in Solo, Indonesia, was officially inaugurated by President Joko Widodo on August 9, 2017 as another symbol to strengten the label of Solo as "The City of Culture". In its very young age, the museum has a strong potential to exist in international level due to: 1) its great number of kris collections that reach to 1,500 kris and other traditional weapons; 2) kris recognition as one of world heritages by UNESCO on November 25, 2005, which "it was later encryptioned in Representative List of Humanity UNESCO in 2008" [1]; and 3) kris as an Indonesian typical cultural product and a symbol of local wisdom. The kris distinction and uniqueness unavoidably make foreign people curious and, therefore, look for kris information through various media and even make a visit to Solo, Indonesia. The potential requires a support to revamp MKN so that MKN is ready to go international. One of the main supporting aspects is to provide information about kris in MKN in English since the principal of a language as a means of communication becomes a key success to realize the functions of a museum, as stated in the Strategic Plans of National Museum 2015-2019 [2], they are 1) as a place to conserve culture; 2) as an educational place; 
3) as a fun recreational place; 4) as a window of culture; and 5) as a center for research, culture and information.

A great quantity of information about kris in Museum Keris Nusantara is mainly provided in the form of storylines, an informative device telling a worth remembering story that draws museum visitors' attention so that they will leave the museum with a complete instead of scattered story. However, MKN has not had any English version of storylines to display to its foreign visitors, which actually play an important role in providing them significant information about kris. Thus, the internationalization process of MKN through the availability of information written in English is critical to do.

\subsection{Storylines in MKN}

Storyline is "a succinct narrative that represents the most important aspects of museum exhibit's themes, messages and their relationship" [3] so it has a high priority to help museum visitors in understanding museum's displayed collections. Storyline will give initial references for visitors in grasping elaborative information of a caption - a label having limited description of a given collection - because storyline could possibly be provided in the form of short history narration or collection's general description. Often, storyline is presented in a clipped combination of information and graphics called infographics - 'a collection of imagery, charts, and minimal text that gives an easy-to-understand overview of a topic that aimed to communicate information quickly and clearly ${ }^{6}$ [4]. Museum storyline should pay attention to visitors' readability aspect since the visitors come from different age, education, profession and interest, starting from children, adults, passionate history lovers, to scholars. Robertson [3] underlined the importance of recognizing museum visitors because storyline presentation is hoped to ease readers in digesting information, and not making it complicated to understand.

Storylines in MKN function to explain about general description of kris, parts of kris, and history of kris. They are displayed on each floor of the museum. Storyline about types of pamor (motif of kris blade), for instance, could be found in the main lobby of the first floor, ones about history of kris in Southeast Asia (see Figure 1) and parts of kris are on the second floor (see Figure 2), and another about the process of making kris is presented on the third floor (see Figure 3). In fact, storylines take a big portion in reinforcing the MKN activities for the sake of educating visitors. Thus, that becomes the reason of why we refer storylines to "the heart of MKN“.

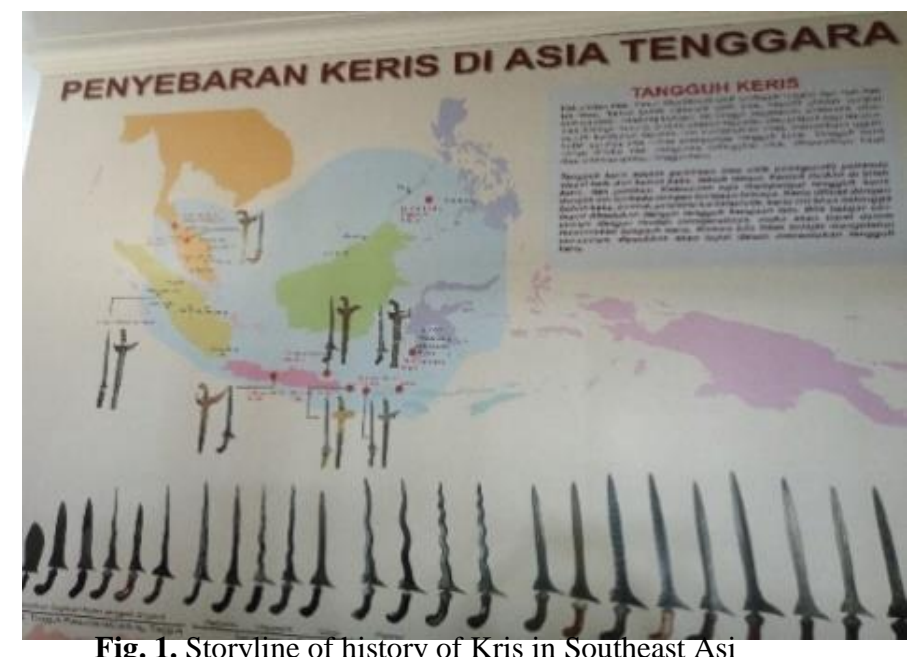

Fig. 1. Storyline of history of Kris in Southeast Asi 


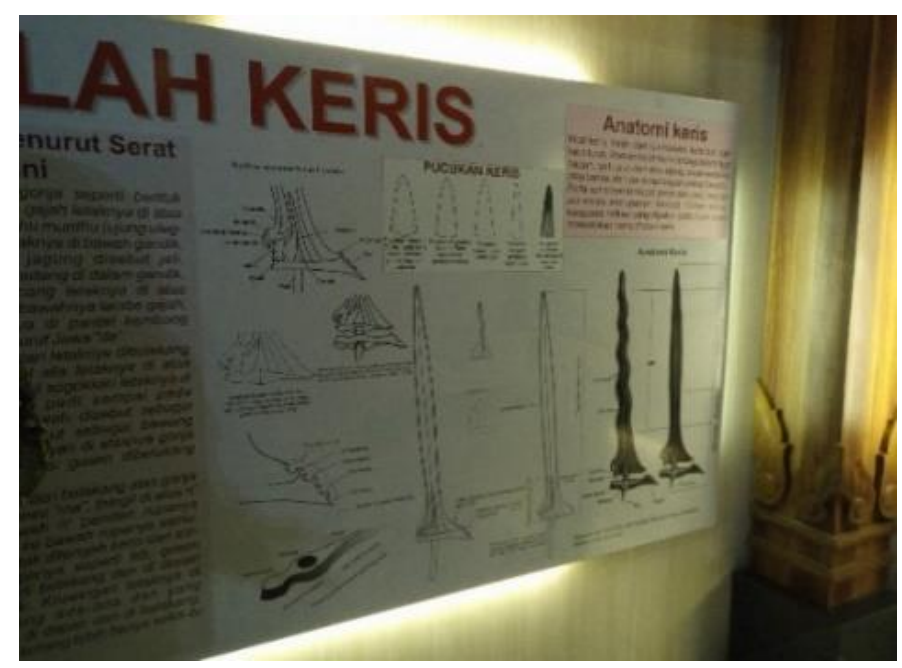

Fig. 2. Storyline of kris anatomy

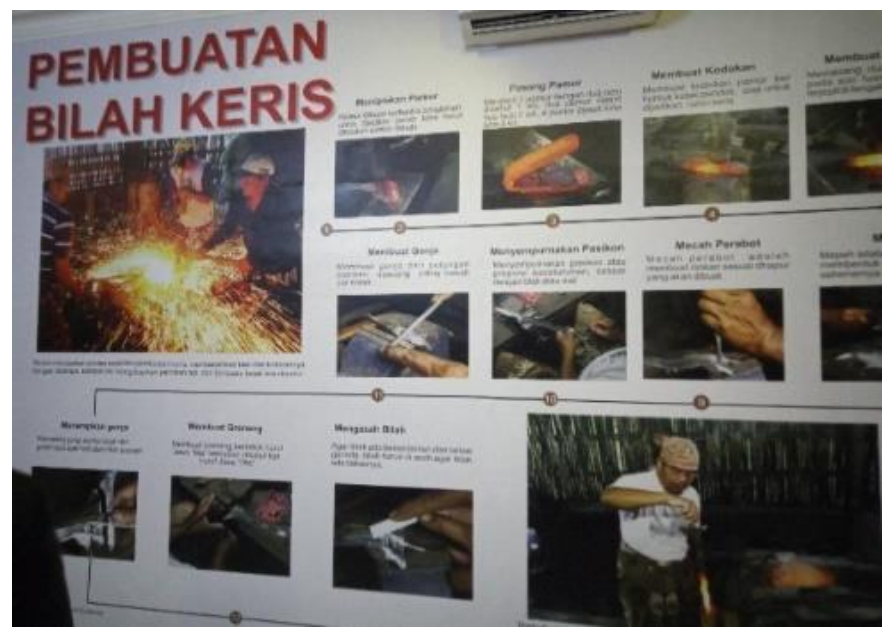

Fig. 3. Storyline of Kris making process

Looking into the storylines in figure 1,2, and 3, there are a big number of kris terms within them, such as tangguh, warangka, pendhok, mendhak, lambe gajah, gandik, gonja, greneng, sor-soran, ricikan, pamor, kodokan, pasikon, bilah, and many more. For lay persons, especially for elementary students and high school students who often visit MKN, those terms hamper their reading process. They even probably read them for the first time when having a tour in the museum. Foreign tourists would also share the same experience as them. Their challenges are getting bigger when they could not find any other helpful information and supporting media provided in English, as well as tourist guides having good English speaking. As a result, their 
big curiosity about kris fades away. This case becomes a main obstacle MKN needs to solve unless the museum could not survive in the future.

\subsection{Generic structure of storylines}

Seen from their function, i.e. as an effective medium to communicate to visitors, texts in storylines are realized in descriptive texts and recount texts. Descriptive storylines explains museum collections in detail, of which structure consists of identification and description. It starts with an introduction of the given collections and is accompanied by detailed description of them. Let us take a storyline of Nogo Sosro Kris as an example. Identification part offers information about what Nogo Sosro Kris is and how people interpret its existance. Description part of it covers comprehensive information about the kris shape, characteristics, function, and specific segments. In addition, Gerot et al. [5] mentioned that a language feature typical in a descriptive text is the operation of technical terms. This feature also emerges in MKN storylines, where there are abundance of kris terms and Javanese cultural terms applied. Besides that, the use of adjectives, adverbs, nouns, pronouns, and action verbs are often presented in the text. They also explained that the generic structure of a (storyline) recount text comprises orientation, arrangement of events, and reorientation. Its dominant language features utilized are: 1) definite adverbs of time (yesterday, last year); 2) personal pronouns (I, we, my team); 3) chronological conjunctions (first, then, after that); 4) action verbs; and 5) adjectives. In addition to language features, the content of a storyline is also a predominant point to ponder. The process of arranging and developing a story has to examine target visitors in order to successfully build communication and raise visitors' interest to gain messages delivered by a museum. Storylines manifestated in a recount text have a form of narration, which commonly tells the history of museum collections, such as the history of kris in Southeast Asia in figure 1.

\subsection{Quality Translation}

To achieve quality translation of storylines, translation assessment aspects needs to be taken into account. According to Tytler as cited by Bell [6] 'translation should give a complete transcript of the ideas of the original work' (p.11). The concept is popularly known as accuracy - one important translation quality assessment to refer to a meaning equivalence of the Source Text (ST) in the Target Text (TT) [7]. The statement mentions a word equivalence, which is defined by Machali [8] as the exactness in reproducing message (of the ST) that needs to be considered in translation.

In addition to accuracy, the level of naturalness (of the translation product) becomes another significant aspect to underline. It is understood by Newmark [9] as 'the level of natural usage in grammar/ syntactic structures and lexis' and natural usage, as he mentioned, are distinct from ordinary language because "naturalness depends on the relationship between the writer, the readership and the topic or situation' (p.29). A requirement of 'reading as an original' [7] from readers' side determines the key to make an high-acceptable translation.

\subsection{MKN Challenges}

The problem of MKN of not owning the English version of storylines, is attempted to be responded by English Diploma 3 Program of UNS (ED 3 UNS), i.e. by sending sixth semester students in an internship program. Since 2018, MKN has been receiving 10 students of ED3 UNS with their main project of translating MKN captions and storylines into English. However, the project outcome is assumed to be not having satisfactory end result due to the students' less competency in translating. Their translation quality is presumably not well-guaranteed because they are novice translators - those who are still lack of demonstrating critical language 
competency that obstruct them from making essential improvements on their TT and have difficulties in creating a link between their work and the contexts of the text they are translating [10]. In addition, translating kris terms is a real challenge for them, due to the unavailability of bilingual kris dictionaries. Kris and all of its related parts are full of philosophycal and symbolical values [11]. For Javanese people, kris is not merely a physical object of a weapon, but is a tosan aji, sacred heirloom weapon that is special in its shape, making process, faith, and spiritual values [12].

It is effortless to find references discussing on kris and its technical terms, like articles entitled Keris sebagai Salah Satu Kebudayaan Materi by Priyanto [12], Keris dalam Perspektif Keilmuan [11], Ensiklopedi Keris [13], and Tafsir Keris [14]. Along with the advance of technology development, modern products about kris have been created in order to ease people who are looking for information about kris. An Android-application-based dictionary Kamus Keris Lengkap (Complete Kris Dictionary) by Arya Buana Diwangkara, for instance, offers users brief definition of kris terms arranged alphabetically in Indonesian, and Buku Saku Bahan Ajar Keris (Pocket Book of Kris Teaching Material) published by Education Authorities of Kediri, East Java, is written for educational purposes. In fact, bilingual dictionary of kris (Indonesian-English) are still very hard to find in Indonesia.

Researches on translation of cultural terms have been massively done by many scholars. Many of them discuss sub type of culture-specific terms, such as researches on : 1) translation of food names [15]; 2) translation of Chinese -English dish names [16]; 3) techniques of translating culture-specific items in tourism promotion campaign [17]; and 4) techniques of translating culture-specific features in food recipes [18]. Those researches firmly prove that a study on kris translation from Indonesian to English has not been conducted so far.

Therefore, the rationales of: 1) less competent translators; 2) big challenges in translating kris terms; 3) unaccessible bilingual kris dictionaries; and 4) insufficient studies on kris translation, lead to the significancy of this study.

\section{Research Method}

This descriptive study is completed by doing three steps. First, interviewing with 10 intern students of ED3 UNS who did internship activities in MKN and distributing questionnaire through Google Form to them were done. Questions given were focused on their prior knowledge about kris, their process of translating storylines, their problems when rendering message of the storylines, and their ways to solve them. Second, textual analysis of the students ${ }^{6}$ translated storylines was done by comparing the original text written in Indonesian and the Target Text (TT) in English. This step was mainly purposed to identify the roots of the problems, whether they came from the Source Text (ST) or the students - or even from both of them. ST analysis covered an examination on its generic structure and language features, on both descriptive storylines and recount storylines. The obtained findings were then pulled closer to the problems faced by the students, i.e. by grouping the identified problems into linguistic issues, cultural challenges and subject matter problems. Next, to strengthen the findings of the first two steps, scrutinizing the students ' internship reports was intensively conducted in order to gain authentic data of their translation challenges. 


\section{Result and Discussion}

After completing the designed steps as briefly explained above, results of this study show that the process of translating MKN storylines is hard to do by the 10 interns students and it is mainly due to the frequent presence of Javanese culture-specific terms. Two conditions influence the case. First, the students do not possess any prior background knowledge about kris although majority of them are Javanese. They even rare and never know various kris terms before conducting internship activities in MKN. Second, all of them admitted that they did not have any experience in translating Javanese-culture-related texts, whereas all storylines provided in MKN contain Javanese cultural terms exploiting Javanese philosophy, values and symbols, such as kris components, sesajen (Javanese offerings), fundamental process activities in kris making, etc.

The two conditions, in fact, affect the students' translation process. Referring to three stages of Nida \& Taber's [19] translation process, namely analysis stage, transferring stage, and restructuring stage, none of the students carried each of them smoothly. In the first stage, they took longer time to recognize Javanese terms and kris terms (see table 1) that are unfortunately written within less quality ST. The defection lies on the incomplete sentence structure, wrong sentence structure, and lack of sentence coherency (see table 2).

Table 2. List of some difficult terms to translate in English

\begin{tabular}{ll}
\hline Javanese culture-related terms & Kris terms \\
\hline sesaji & jejeran \\
tumpeng & dhapur \\
jenang & pamor \\
jangan bening & pendhak \\
sekul wuduk & warangka \\
ingkung ayam & gonja \\
sekul magana & lambe gajah \\
akhil balik & gandhik \\
kabusanan & pendok \\
Pengulu enem & jenggot \\
Ngabehi Jararaga & mendhak \\
gatu munthu & selut \\
jangkep & bunton \\
gemah ripah loh jinawi & krawangan \\
\hline
\end{tabular}

Table 2. Examples of ST defection in MKN storylines

\begin{tabular}{lll}
\hline ST defection & Case & Examples \\
\hline Incomplete sentence & the absence of sentence & Kartasura terpecah menjadi dua yaitu \\
structure & predicate and subject & Surakarta dan Yogyakarta, perjanjian \\
& & lisan antara Sunan Pakubuwana II dan \\
& & Pangeran Mangkubumi, Surakarta (?) \\
dan (?) nganggit atau merancang bentuk & \\
& & yang baru. \\
Incomplete sentence & Menurut keterangan Ngabehi Jararaga \\
structure & the absence of sentence & dalam manuskrip "Kawruh Jejeran" \\
& & Surakarta (?) berbentuk Tunggak Semi.
\end{tabular}


Incomplete sentence

structure

Incomplete sentence

structure

Wrong sentence structure

Lack of sentence coherency
The absence of sentence subject

The absence of sentence subject

Incorrect use of double predicates

The absence of repetition of key noun
Melingkar sampai dibawahnya lambe gajah, (?) dinamakan jenggot letaknya dipantat kembang kacang berbentuk huruf Jawa "dha".

Untuk memenuhi fungsinya (?) harus diberi hulu, disebut jejeran atau ukiran keris.

Keris dianggap sebagai pusaka diturunkan dari bapak ke anaknya.

Mendhak Surakarta berukuran sedang, tidak tinggi seperti Banyumasan dan Jawa timuran, tidak rendah seperti mendak Yogyakarta. Pada dasarnya (?) ada 4 bentuk baku yaitu, widengan, parijoto dan bejen, meskipun ada bentuk lainnya bukan merupakan bentuk baku.

The case in table 2 above demands the students to revise the ST before continuing to the next stage called transferring process. In understanding the meaning of unfamiliar Javanese terms and kris terms, they needed some times to consult with the museum curator and senior tourist guide of MKN, as well as to do researches by looking for references about kris in the internet and books and magazines in the museum library. Consultation was done primarily to dig information about: 1) what books they could refer to to help them find the definition and meaning of the terms; 2) detail explanation of kris making; 3) stories behind kris and its history; 3) Javanese terms meaning; 4) advantages of kris; and 5) meaning of kris components. The students stated that direct consultation session was the most meaningful one since they could comprehend the meaning and definition of the terms easily.

The second stage of transferring ST message was the hardest one to do since they experienced unexpected occasion where the students could not find the equivalence of the terms in English. Some of Molina and Albir's [20] translation techniques were applied, i.e. borrowing the kris terms into English, generalization, established equivalence, literal translation, adaptation and description by giving additional information (see some of the examples in table 3). Each of them gives different impact to the translation quality. And the third stage, restructuring stage, was done by revising their translation based on the supervisor's suggestions and their second independent check.

Table 3. Translation techniques applied to translate Javanese cultural terms and kris terms

\begin{tabular}{lll}
\hline ST & TT & Translation techniques \\
\hline selut & selut & borrowing \\
ukel pancing & ukel pancing & borrowing \\
jejeran & jejeran (handle of a kris) & borrowing and description \\
panggang tumpeng & roasted tumpeng (Javanese & borrowing and description \\
& traditional cone-shaped rice) & \\
gemah ripah loh jinawi & peaceful, prosperous, and fertile & adaptation \\
sekul warna-warni & colorful rice & establised equivalence \\
warangka & sheath & generalization \\
lambe gajah & elephant's lips & literal translation \\
kembang kacang & peanut flower & literal translation \\
hulu & upstream & literal translation \\
\hline
\end{tabular}


Textual analysis was done by comparing the ST and TT in order to assess the students، translation accuracy and its naturalness. Accuracy of their transation is focused on the exact ST meaning delivery that also covers meaning aspects of Javanese culture, symbol, philosophy, and values. And naturalness is seen from the usage of natural dictions and sentence structure in TT. Results show obviously that the students" storyline translations are less accurate due mainly to the context ignorance and the application of literal translation technique in translating cultural terms. In terms of naturalness, the translations are still categorized as less acceptable. Let us see the examples.

Example 1

ST: Keris tak dapat dipisahkan dari perabotnya, fungsi utama keris adalah sebagai senjata. Untuk memenuhi fungsinya (keris) harus diberi 'hulu', (yang) disebut 'jejeran ' atau ukiran keris. Keris harus diberi 'warangka 'agar mudah dibawa dan tidak melukai penggunanya.

TT: Kris cannot be separated from its components. The main function of a kris is a weapon. To fulfil its function, kris should be given the upstream, called jejeran or hilt. Kris should have warangka or sheath so that it is easy to carry and does not hurt the owner.

Example 2

ST: 'Mendhak' Keris dipasang diantara 'jejeran' dan bilah keris. Mendhak Surakarta Berukuran sedang, tidak tinggi seperti Banyumasan dan Jawa timuran, tidak rendah seperti mendak Yogyakarta. Pada dasarnya ada 4 bentuk baku yaitu, 'widengan", 'parijoto ' dan 'bejen', meskipun ada bentuk lainnya bukan merupakan bentuk baku.

TT: Mendhak kris is applied between hilt and blade of kris. Mendhak Surakarta has medium sized, not as high as Banyumasan and East Javanese, and it is not as short as mendhak Yogyakarta. Basically, there are 4 basic forms namely, widengan, parijoto and bejen, although there are other forms which have no standard forms.

Example 1 talks about the function of a kris and its general components. Seen from the accuracy aspect, the result text is already equivalent since the translator could deliver the main message of the original text, but s/he seems still to face difficulty in translating the given kris terms, particularly the term hulu. Hulu means ujung (top). It collocates with several words in Indonesian, such as sungai (river), orang (people), and pisau/keris (knives/ kris), but it requires different terminology when translated into English. Hulu Keris, in this context, is equivalent with handle of a kris or hilt to be more precise. So, translating the word hulu literally into upstream only creates confusion for readers as it is not habitually juxtaposed with the word keris but is instead associated with sungai (river).

Example 2 shows different problem performed by one of the students in producing natural translation result. Linguistic problem is identified here, in which s/he failed in providing correct dictions usage and well-structured English sentences. Let us look into the first sentence of the example.

ST: 'Mendhak' Keris dipasang diantara 'jejeran' dan bilah keris.

TT: Mendhak kris is applied between hilt and blade of kris. 
Problem raised in the translation is the use of the word dipasang. The ST tells us that mendhak (see figure 4 and figure 5), a ring-shaped accessory positioned on the kris handle that is made of gold, silver, or brass and is even added with diamonds and gems [21], is structured in the position of between jejeran (hilt) and bilah (blade) of a kris.

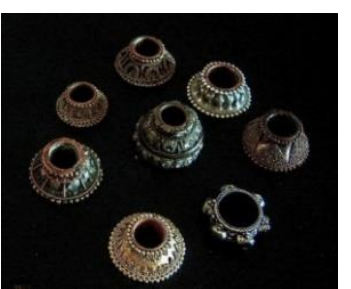

Fig. 4. Mendhak in various shapes, sizes, and materials

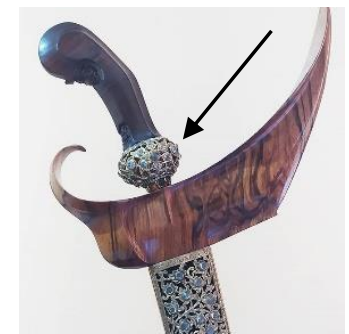

Fig. 5. Position of mendhak in a kris

In the TT, the words is applied has nothing to do with the meaning of is structured, since the words in English refers to put something in a surface and use something in a situation or activity. As a result, the mistake could mislead its readers. The word dipasang, based on the analysis of kris making context, is better translated into assemble (put different part together) so that the translation should be Mendhak is assembled between hilt and blade of Kris. Another problem in example 2 is the way the student presents the English sentences. S/he made mistakes in using the word size. It has to function as a noun (size), not as an adjective (sized). English syntax of degree of comparison is incorrectly and inconsistently used, too. In addition, knowledge of mendhak needs to be understood before translating this part so that the translator does know what mendhak Surakarta, mendhak Banyumas, and mendhak Yogyakarta mean. Deep research about typical mendhak with particular size, shape, materials, and social status of the owner is a must to be done so that the translator is not trapped in translating it literally without acknowledging the philosophy and symbol behind the term. Thus, our proposed translation (TT-1) would be like below.

TT-1: Mendhak is assembled between hilt and blade of Kris. Mendhak Surakarta has medium size. It is not as high as Banyumas's and East Java's typical mendhak and is not as short as Yogyakarta's. Basically, there are 4 basic forms of mendhak, namely widengan, parijoto, bejen, and another form having no standard form. 
Example 3

\author{
ST: Rangkaian Sesaji Pembuatan Keris \\ Sekul warna-Warni \\ Tumpeng Janganan \\ Tumpeng warna-warni \\ Sekul megana kebo siji, jangan bening, pecel pitik areng jati
}

\title{
TT: A Series of Offerings in Kris-making
}

Colorful Rice

Vegetables Tumpeng (Javanese traditional cone-shaped rice)

Colorful Tumpeng (Javanese traditional cone-shaped rice)

Megana rice one buffalo, clear soup, chicken pecel (steam vegetables with nut sauce)

Another challenge for the translator is the traditional Javanese food name made for the offering. It requires a great deal of work to arrive at the equivalence in translation. The English version of the storyline includes some examples of failed translation. The application of the literal translation technique triggers to a less accurate message, such as the translation of kebo siji into one buffalo. The meaning of the TT is a puzzle and completely unacceptable. Kebo siji as one of the elements in the offering package symbolizes the enormous power represented in the slices of buffalo meat. Javanese people firmly believe that this kind of offering can provide them with capacity and prosperity [22]. This prevailing philosophy can be expressed by borrowing the original words in the translation and putting some additional information on the symbols.

\section{Conclusion}

Based on the discussion, it can be concluded that completing a job to translate MKN storylines is proven not easy to do by the 10 intern students of D3 UNS. Their challenges can then be grouped into three main problems, i.e. linguistic problems, cultural problems, and subject matter problems. Linguistic problems cover lack of English vocabularies, less competent in arranging well-structured and acceptable English sentences, and less ignorance in analyzing the context where the culture-specific terms appear. Cultural problems include less consideration in looking into the philosophical aspects, symbol, and values beyond kris terms, which affects the way the students applying translation strategies and its effect on the readers. The last, subject matter problems, deals with the absence of prior knowledge about kris. This is, in fact, the main problem faced by all the students. So, it is not surprising that those challenges give impact on the longer process of translating storylines in MKN and the less quality translation produced.

\section{References}

[1] Setiono, EA. 14 Tahun pasca penetapan UNESCO, Senapati Nusantara desak pemerintah tetapkan 25 November jadi Hari Keris Nasional. Available from: https://lumajangtimes.com/baca/205287/20191125/104500/index.html [Accessed 2nd February 2020]. 
[2] Museum Nasional Indonesia. Rencana strategis museum nasional 2015-2019. Available from: https://www.museumnasional.or.id/wp-content/uploads/2019/09/ RENSTRA-MUSEUMNASIONAL-2015-2019-1.pdf [Accessed 2nd February 2020].

[3] Robertson, A. Storyline: At the heart of your museum. Available from: https://files.townlife.com/public/uploads/documents/16031/Storyline_At_the_Heart_of_Your_Mus eum.pdf [Accessed 4th February 2020].

[4] Nediger, M. What is an infographic? Examples, templates \& design tips. Weblog. Available from: https://venngage.com/blog/what-is-an-infographic/ [Accessed $22^{\text {nd }}$ May 2020].

[5] Gerot, L, Wignell, P. Making Sense of Functional Grammar. First Edition. Sydney: Gerd Stabler; 1994.

[6] Bell, RT. Translation and translating: theory and practice. London and New York: Longman; 1991.

[7] Shuttleworth, M, Cowie, M. Dictionary of Translation Studies. Manchester: St Jerome Publishing; 1997.

[8] Machali, R. Pedoman bagi penerjemah. Bandung: Kaifa; 2009.

[9] Newmark, P. A textbook of translation. London: Prentice Hall; 1988.

[10] Yves, G, Shlesinger, M, Stolze, R. Doubts and directions in translation studies. Amsterdam/ Philadelphia: John Benjamins Publishcing Company; 2007.

[11] Sutrisno, S. Keris dalam perspektif falsafah Jawa: magis, mistis sekaligus simbolis. Keris dalam perspektif keilmuan. Pusat Penelitian dan Pengembangan Kebudayaan Badan Pengembangan Sumber Daya Kebudayaan dan Pariwisata, Kementerian Kebudayaan dan Pariwisata Republik Indonesia: Perpustakaan Nasional; 2011.

[12] Priyanto. Keris sebagai salah satu kebudayaan materi. Jurnal Vokasi Indonesia. 2013;1(1): 35-43. Available from https://www.researchgate.net/publication/328217165_Keris_Sebagai_Salah_Satu_Kebudayaan_Ma teri. [Accessed 4th February 2020].

[13] Harsrinuksmo, B. Ensiklopedi keris. Jakarta: Gramedia Pustaka Utama; 2004.

[14] Junus, T. Tafsir keris. Jakarta: Komunitas Panji Nusantara; 2012.

[15] Peng, A. Translating dish names: food cultural representation in Hong Lou Meng. Open access library journal. 2015;2(e1316). Available from: http://dx.doi.org/10.4236/oalib.1101316. [Accessed 27th October 2016].

[16] Mu, C. English translation of Chinese dish names. Translation Journal. 2010;14(4). Available from: https://translationjournal.net/journal/54dishes.htm. [Accessed 17 ${ }^{\text {th }}$ February 2017].

[17] Narvaez, IC, Zambrana, JMV. How to translate culture-specific items: a case study of tourist promotion campaign by Turespaña. The journal of specialised translation. 2014;21: 71-112. Available from: https://www.jostrans.org/issue21/art_comitre.pdf. [Accessed 23rd May 2020].

[18] Köhler, I. Translating food: how to translate culture specific features in recipes. Available from: https://pdfs.semanticscholar.org/69f6/e4f61629c899560b4e97cae25cceba1bdc3c.pdf?_ga=2.19158 072.1814138553.1580800018-1050314116.1580800018. [Accessed 19th July 2016].

[19] Nida, EA, Taber CR. The theory and practice of translation. Leiden: E.J. Brill; 1982.

[20] Molina, L, Albir AH. Translation techniques revisited: A dynamic and functionalist approach. Meta journal. 2002;47(4): 498-512. Available from: https://www.erudit.org/fr/revues/meta/2002-v47-n4meta688/008033ar/. [Accessed 16th September 2018].

[21] Mardianto, W. Sesuatu mengenai keris dan tombak. Available from: https://www.academia.edu/10046930/A_to_Z_Sesuatu_mengenai_KERIS_dan_TOMBAK_KERIS _SENJATA_TRADISIONAL_INDONESIA_A_to_Z. [Accessed 4th February 2020]

[22] Setiawan, RB. Bentuk, makna, dan fungsi, sesaji mahesa lawung dalam tradisi ritual di keraton Surakarta Hadiningrat. 2015 Available from: https://lib.unnes.ac.id/23139/1/2601411136.pdf [Accessed 26th May 2020]. 